\title{
Citizens' Education Level and Public Participation in Environmental and Spatial Planning Public Policies: Case Study in Lisbon and Surrounds Counties
}

\author{
Vanda Carreira $^{1 *}$, Joao Reis Machado ${ }^{1,2}$, Lia Vasconcelos ${ }^{1}$ \\ ${ }^{1}$ Faculty of Sciences, New University of Lisbon (FCT- UNL), Quinta da Torre, Campus Universitário, \\ 2829-516 Caparica, Portugal \\ ${ }^{2}$ Geographical Institute of Lisbon, Rua da Artilharia, 107, 1099-052 Lisboa, Portugal \\ *vanda.carreira@gmail.com
}

\begin{abstract}
Education assumes a central key role for the adequate functioning of democratic systems, and therefore as a way to better choices and sustainable development. The study was conducted on a sample of 250 subjects $(N=250)$, of both genders, and aimed to 1) evaluate whether citizens' education level influences or not on their participation in environmental and spatial planning public policies. Data was collected, recorded, validated and subjected to statistical analysis. P-values $<0.05$ results were considered statistically significant. The sample was composed of $52 \%$ women and $48 \%$ men, with a mean age of $42.3 \pm 13.2$ years. It was possible to verify that citizens' education level did not influence the type of public participation they were involved $(P=$ 0.960), except in the case of PhD subjects $(P=0.045)$; neither the subjects' opinions regarding the time point to get involved in the participation $(P=0.299)$, neither with the relationship with the local authorities $(P=0.865)$. In contrast, education level influences the way in which citizens exercise their public participation $(P=0.003)$. Concluding, education level influences citizen participation only in terms of how they perceive and carry out their involvement in public policies; but does not influence the fact that they are more or less participatory.
\end{abstract}

Keywords: Education; Citizens; Public participation; Environment; Spatial planning

\section{INTRODUCTION}

The word "participation" means "taking part", "sharing" or "being part of", and it carries with it an active component [1,2]. According to Moron [3] and Duarte [4], participating means intervening in any decision-making process. Moreover, Carreira [5,6] considers participation as an essential element of democratic societies. This is because it constitutes a means of ensuring that the concerns of voters are considered in practical terms, and not just in electoral programs. More recently, Ferreira [7] interpreted it as an engagement process in which stakeholders seek to interact, learn, understand, and at the same time provide relevant information, in a spirit of collaboration towards achieving a representative and fair decision [7,8]. In terms of the public interest, participation is the procedure by which citizens, whether individually or institutionally considered interact dialectically with each other and with the governments they elect. It is a desirable cooperation "ab initio" in making decisions to solve problems that directly or indirectly affect them, and may also be the driving or suggesting of solutions that promote the common good in various fields of public life [5, 6, 9, 10, 11]. It is public participation, with its deliberative qualities, which is most likely to yield positive democratic effects $[8,12,13,14,15,16,17]$. The process of citizen participation provide in some steps opportunities to influence final public decisions [18]. To ensure that citizens' involvement in public decisions which results in goods consequences it is necessary that each of the citizens have knowledge about the issues being discussed. This needed knowledge can partially be provided by public education programs which should be developed presenting a relatively balanced and complete information to stimulate citizens to contribute with their own ideas. Education is directly related to knowledge, and should not be seen as a privilege but as a common and universal right for all citizens, so that they may grasp one of the main instruments of intervention in society [19]. The aim is to join the main stream of progress as a thinking human being, encourage the cessation of its passive and inert condition, and replace it with an active intervention condition and a comprehensive view of the socio-economic environment, with its complex events, where it operates [20]. Therefore, education relates directly to the concepts 
of democracy, public participation, citizenship and sustainable development. It is the best guarantee of the freedom that is necessary for the proper functioning of democratic systems, since it effectively expresses the need to search for information and take action in the way that every citizen should. This will ensure good choices and results, leading to an impact on the political system [21,22,23]. Historically, education has come in many guises and has been approached in diverse ways, however it and has not always been accessible to all individuals; no doubt, it has today become a universal pillar of the creation, support and development of modern societies and democracy.

The present study was developed in a sample of 250 subjects $(\mathrm{N}=250)$ and aimed to 1$)$ evaluate whether citizens' education level influences or not on their participation in environmental and spatial planning public policies.

\section{MATERIALS AND METHODS}

The study was conducted on a sample of 250 individuals $(\mathrm{N}=250)$, of both genders, over the age of 18 and resident in the Lisbon and surrounds counties, and all eligible voters in Portugal. All subjects were required to complete a survey that was specifically designed for this work; this proved straightforward for all participants. The survey was initially based on a previous analysis of existing literature on the subject under study, looking for the presence of coherence in the issues presented in order to obtain information that could be used to meet the set objective [24,25,26,27]. Through our investigation, we sought to learn the characteristics, knowledge, behaviors, values and beliefs of the sample individuals in the context of democracy and public participation, as related to both the environment and the spatial planning context in which they live. In order to detect any deficiencies in the final investigation, we first conducted a test using a pilot survey on a small group of 25 subjects $(\mathrm{N}=25)$, which corresponded to $10 \%$ of the total sample that we wished to target (Gill \& Johnson, 2010). After this pilot test, we performed any necessary adjustments before applying the final survey to the entire sample. The survey was of the mixed type and was developed to comprise 45 questions, including closed-answer questions (28) and short open-answer questions (15), and was divided into six dimensions or main axes, as follows: 1) personal; 2) social; 3) county; 4) information; 5) decisionmaking and 6) public participation. For each of these dimensions, several points were combined in order to obtain the maximum amount of information that would reflect the reality of the subjects' lives. As each individual completed each of the survey's dimensions, it became possible to obtain results that allowed us to move in sequence towards answers to our most complex questions. Data was collected, recorded and validated to maintain its reliability in terms of reflecting the views of various stakeholders, as suggested by Rowe et al. [28]. Later, the information was processed in a database and subjected to descriptive and inferential statistical analysis using Microsoft Excel (Microsoft Office 365) and the Statistical Package for Social Sciences - SPSS (SPSS v.21.0) software. Dispersion measures such as minimum, maximum, mean and standard deviation were calculated. The analysis of data normality was achieved using the Kolmogorov-Smirnov test (KS). Since most of the variables did not have a normal distribution, it was decided to use a non-parametric-type test, specifically the chi-square test of independence, in order to perform categorical data analysis once variables of the same nature were analyzed. This was also done because the aim of the study pointed to the possible existence of a relationship between the variables under study. Citizen participation in the environment and spatial planning public policies was considered to be the dependent variable; that is, the one that we intended to study from the perspective of the influence of varying education levels. For the statistical study p-values $<0.05$ results, were considered statistically significant $[29,30,31,32,33,34$, $35,36]$.

\section{RESUltS}

The sample was composed of $52 \%$ women and $48 \%$ men, with a mean age of $42.3 \pm 13.2$ years (minimum 18 and maximum 71 years). The highest percentage of individuals had an age between 30 and 39 years old (31.2\%), followed by the group aged between 40 and 49 (23.2\%). Regarding marital status, most were married (36.8\%), followed by single (35.2\%), divorced (27.2\%) and finally widow(er)s $(0.8 \%)$. In terms of education level, it was found that $35.8 \%$ had an integrated master's degree, $20.3 \%$ had completed their $2^{\text {nd }}$ schooling cycle and $12.2 \%$ had accomplished the $3^{\text {rd }}$ cycle. $5.7 \%$ were without any educational level, $4.9 \%$ had done the $1^{\text {st }}$ cycle, $4.1 \%$ had a master's science degree and $2.4 \%$ had a doctoral $(\mathrm{PhD})$ degree (Table 1). Using the KS test, it was possible to show that majority of variables did not present normality; as a result, we used the non-parametric tests to 
attain inferential statistics. It was observed that all individuals (100\%) with a $\mathrm{PhD}$ participated in public policies. For all other levels of education, only a minority participated, especially individuals at the $12^{\text {th }}$ school level (44.4\%) and those without any educational level (42.9\%). Individuals with the $2^{\text {nd }}$ cycle who participated accounted for $32 \%$ of the sample, while those with the $1^{\text {st }}$ or $3^{\text {rd }}$ cycle or a bachelor's degree accounted for $33.3 \%$. Using the chi-square test, it was possible to relate citizens' education level with the type of public participation they were involved in, which verified that there was no significant correlation between the two $(\mathrm{p}=0.960)$, except in the case of $\mathrm{PhD}$ subjects $(\mathrm{p}=$ 0.045) (Table 2, Figure 1). It was the opinion of all subjects that their participation in environmental and spatial planning public policies should occur early in a project. It was observed that $40 \%$ of individuals with the $3^{\text {rd }}$ cycle considered that such participation should take place before the project; this view was shared by $33.3 \%$ of those with the $1^{\text {st }}$ cycle, $20 \%$ of those with a master's and $18.2 \%$ of those at an integrated master's level. Conversely, $20 \%$ of individuals with a master's science degree and $2.8 \%$ with an integrated master's were of the opinion that people's involvement in county-solving problems should happen after the project. It was also possible to verify that their education level did not influence the subjects' opinions related to the stage of a project at which citizens should get involved in decisions $(\mathrm{p}=0.299)$ (Table 2 , Figure 2$)$. It was observed that all $\mathrm{PhD}$ individuals participated in a completely voluntary manner, which was contrary to the finding for all individuals with the ${ }^{1 \text { st }}$ cycle and for most subjects from the remaining education levels, who considered that they should only participate if requested to do so. According to the chi-square independence test, it was observed that education influences the way in which citizens exercise their participation in environment and spatial planning public policies $(\mathrm{p}=0.033)$; individuals with higher study levels are more likely to volunteer (Table 2, Figures 3 and 4). Regarding the quality of the relationship between citizens and the administrative authorities, it was found that $22 \%$ of individuals with the $12^{\text {th }}$ level felt it was "good", this percentage was $12 \%$ for those with the $2^{\text {nd }}$ cycle, $6.7 \%$ for those who had the $3^{\text {rd }}$ cycle and $4.5 \%$ for those with an integrated master's. Except for individuals with no education level $(42.9 \%)$ and those who were at the $12^{\text {th }}$ grade (44.4\%), most of the people with other education levels considered that their relationship with the local authorities was "reasonable"; while $57.1 \%$ of individuals with no education level reported having a "bad" relationship. The results of the chi-square test revealed that there was no statistically significant association between the two variables, leading to the conclusion that they were independent $(\mathrm{p}=0.865)$ (Table 2).

Table1. Sample characterization for the age, gender, marital state, level of education parameters

\begin{tabular}{|c|c|c|c|c|c|c|}
\hline Parameter & $\mathbf{N}$ & \multicolumn{3}{|c|}{ Category } & \multirow{2}{*}{$\frac{\mathbf{F r}}{4}$} & \multirow{2}{*}{$\begin{array}{l}\text { Pv (\%) } \\
1.6\end{array}$} \\
\hline \multirow{6}{*}{ Age } & \multirow{6}{*}{250} & $\bar{x}$ & 42.30 & \multirow{6}{*}{$\begin{array}{l}20 \text { years } \\
{[20-30[\text { years }} \\
{[30-40[\text { years }} \\
{[40-50[\text { years }} \\
{[50-60[\text { years }} \\
{[60-70[\text { years }} \\
>=70 \text { years }\end{array}$} & & \\
\hline & & SD & 13.24 & & $\begin{array}{l}38 \\
78\end{array}$ & $\begin{array}{l}15.2 \\
31.2\end{array}$ \\
\hline & & & & & 58 & 23.2 \\
\hline & & min. & 14 & & 44 & 17.6 \\
\hline & & $\max$ & 71 & & 20 & 8.0 \\
\hline & & & & & 8 & 3.2 \\
\hline \multirow{2}{*}{ Gender } & \multirow{2}{*}{250} & Male & & & 120 & 48.0 \\
\hline & & Fema & & & 130 & 52.0 \\
\hline \multirow{4}{*}{ Marital state } & \multirow{4}{*}{250} & Singl & & & 88 & 35.2 \\
\hline & & Mari & & & 92 & 36.8 \\
\hline & & Divo & & & 68 & 27.2 \\
\hline & & Wido & & & 2 & 0.8 \\
\hline \multirow{9}{*}{ Education level } & \multirow{9}{*}{250} & With & lucation & & 14 & 5.7 \\
\hline & & $1^{\text {st }} \mathrm{cy}$ & & & 12 & 4.9 \\
\hline & & $2^{\text {nd }} c y$ & & & 50 & 20.3 \\
\hline & & $3^{\text {th }} \mathrm{cy}$ & & & 30 & 12.2 \\
\hline & & $12^{\text {th }}$ & & & 18 & 7.3 \\
\hline & & Bach & & & 18 & 7.3 \\
\hline & & Integ & Master & & 88 & 35.8 \\
\hline & & Mast & Science & & 10 & 4.1 \\
\hline & & Doct & & & 6 & 2.4 \\
\hline
\end{tabular}


Vanda Carreira et al.

Table2. Influence of the citizen's education level on public participation rate. Statistically significant results for $P$-values $<0.05$

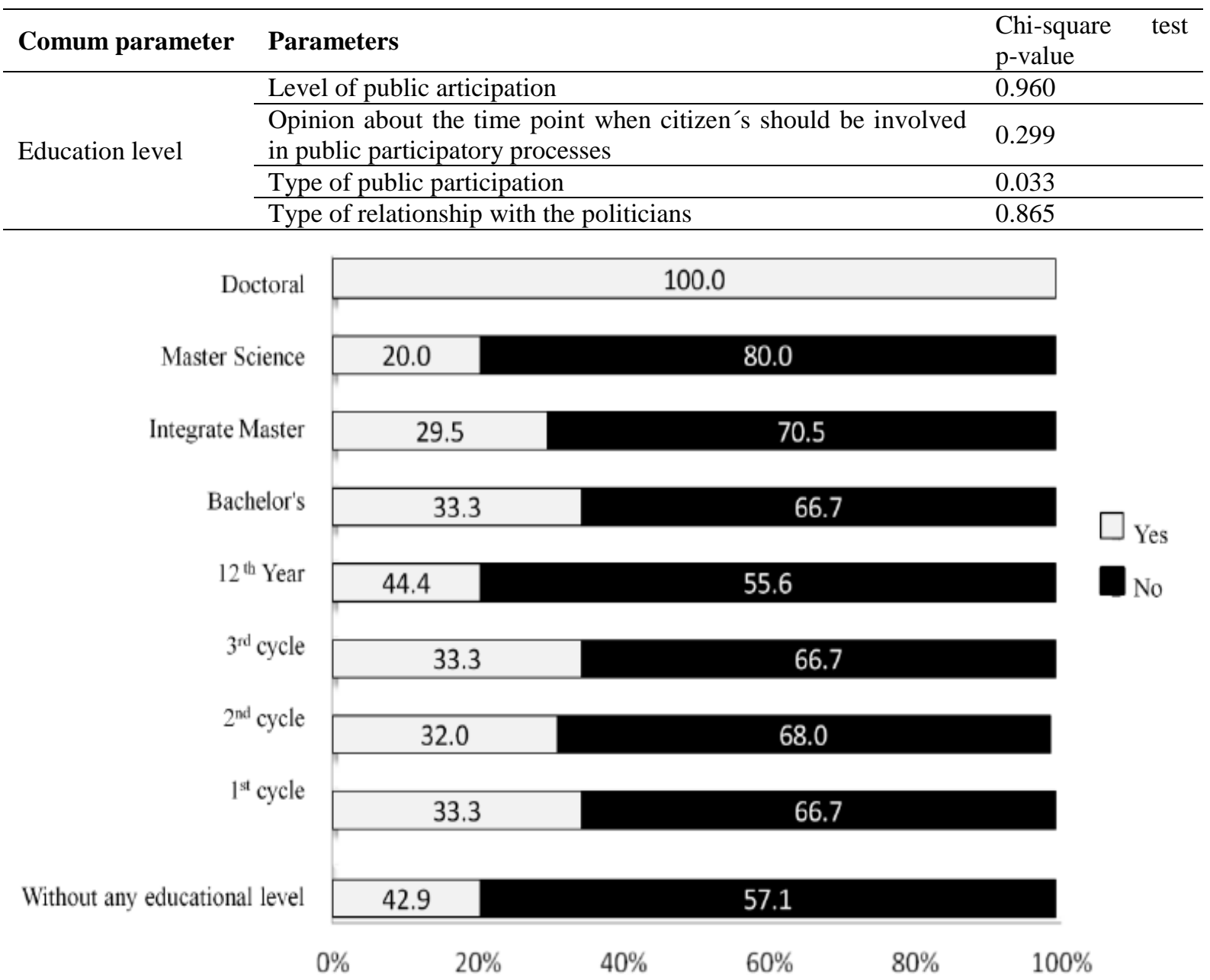

Figure1. Relationship between the level of education and the type of participation

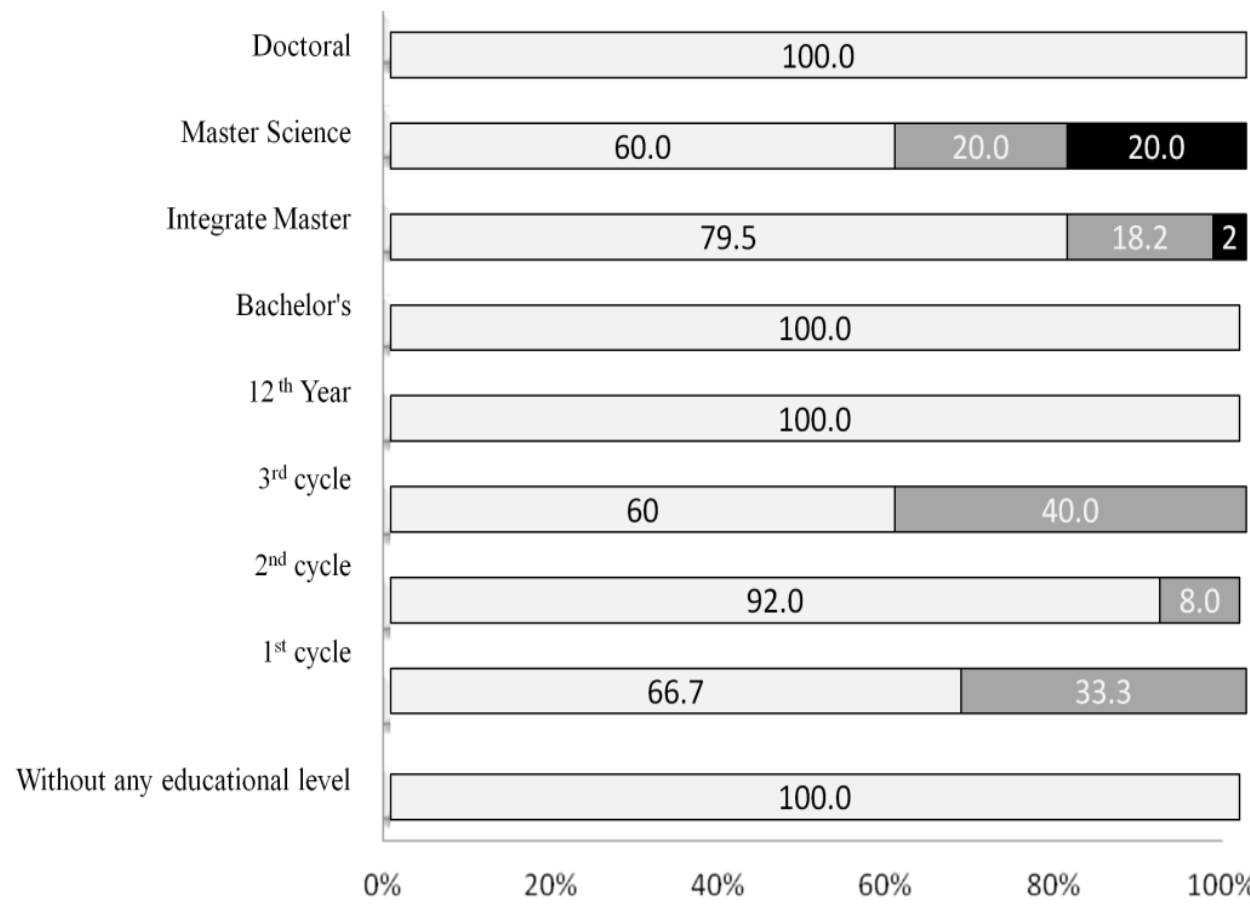

At beginning

Before the project

After the project

Figure2. Relationship between the level of education and the type of participation and the time point which each individual think that citizen's should be involved in the public participation processes 
Citizens' Education Level and Public Participation in Environmental and Spatial Planning Public Policies: Case Study in Lisbon and Surrounds Counties

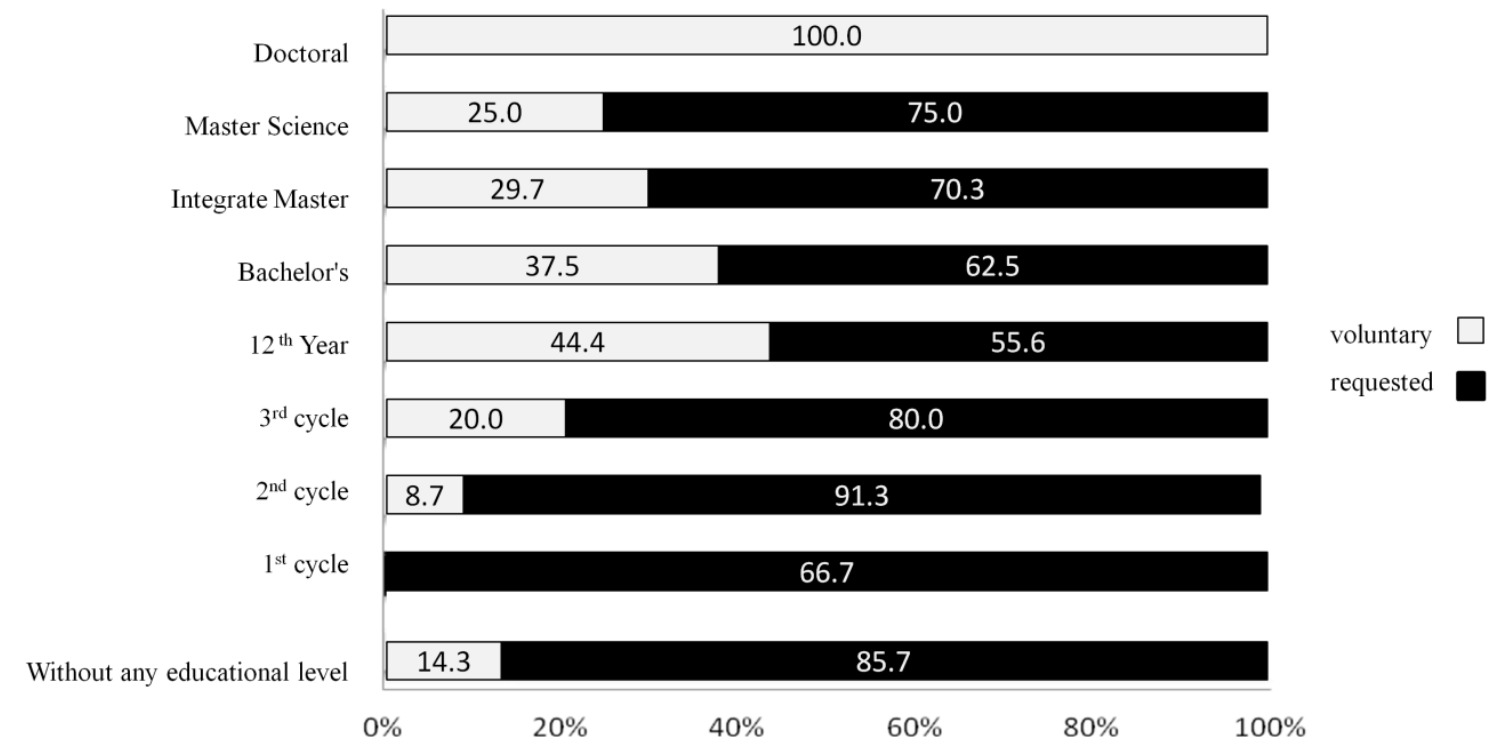

Figure3. Relationship between the level of education and the type of participation and the way each individual participate in public processes

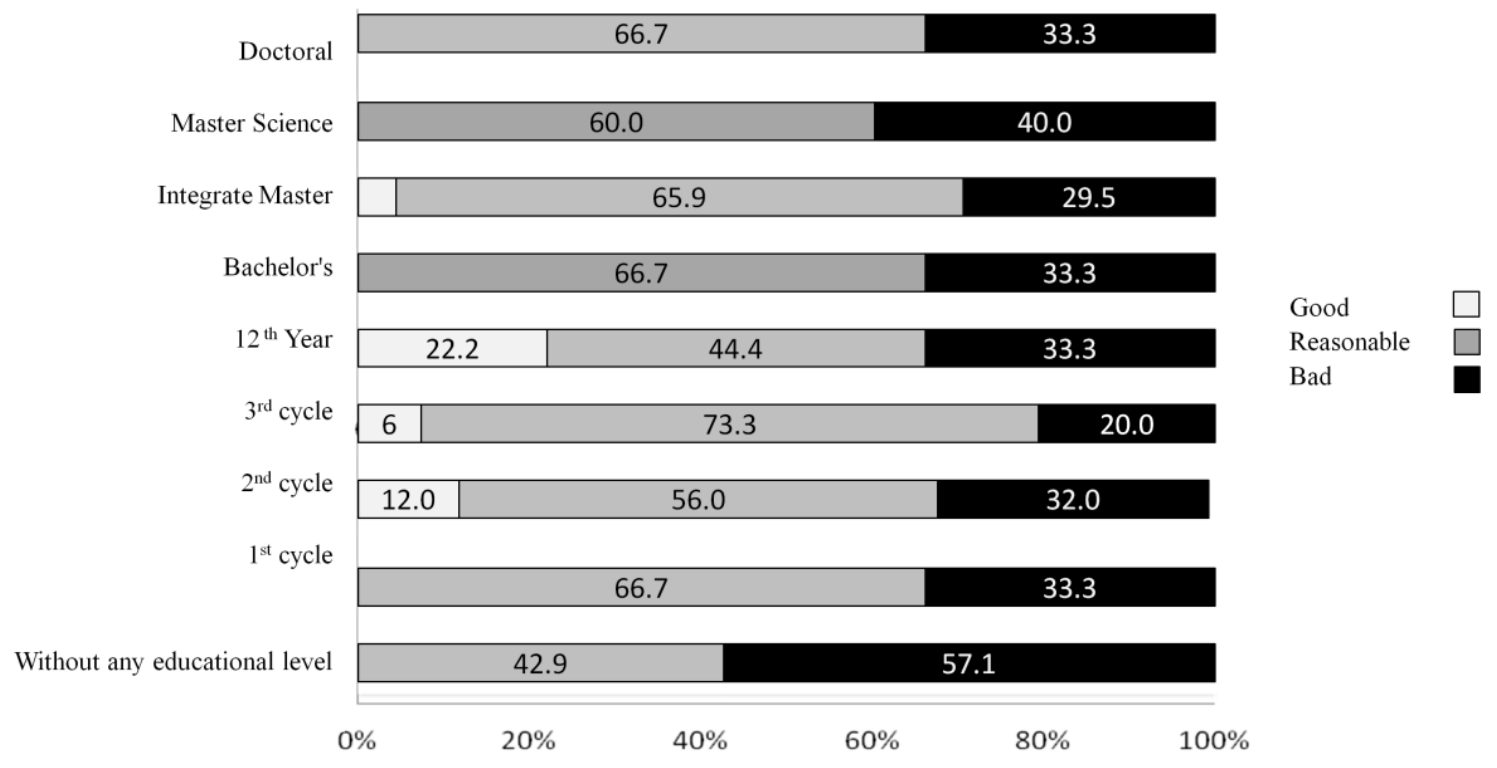

Figure4. Relationship between the level of education and the type of participation and the relationship with the politicians

\section{DisCUSSION}

In general, the sample approached a clear picture of the characteristics of the Portuguese population, enabling us to extrapolate and adapt the results to the national context. With regards to the gender of the subjects, the sample was very balanced, with $52 \%$ women and $48 \%$ men; this closely equates to the balance of genders for the entire Portuguese population, where females constitute $52.1 \%$ and males account for $47.9 \%$ [37]. This achievement of gender equity in the sample is important because it allows for an accurate representation of women's and men's points of view on the issues placed in the different axes of analysis that form the structure of the survey. The average sample age was 42.3 years, representing about $31.2 \%$ of the study participants; this was very close to the average age of the Portuguese population, which is 41.7. With regards to the age groups of individuals, there was likewise a concordance between the sample and the Portuguese population; the subjects were aged > 65 years, which showed larger differences (albeit in a very discreet way) between the sample and the Portuguese general population, with a value of $17.6 \%$ in the first and $19.4 \%$ in the second [37]. About $47 \%$ of the national population is married, a figure that is close to the corresponding $40 \%$ of respondents. Similarly, almost $40 \%$ of the population is single; this proportion was $35.2 \%$ in our. 
When it came to the percentage of those who were divorced, there was a larger discrepancy with $6 \%$ of the populace falling into this category; in the sample, it was $27.2 \%$ [37]. The sample displayed a good education level in general, compared to the wider population; $42.3 \%$ of our group had some sort of degree (undergraduate, integrated master's, master's of science or doctorate) as opposed to the national figure of $16.5 \%$ [37,38]. These results were very important, because the education level possessed by most of the sampled individuals ensured that they were competent to answer the questions in a credible way. At present, it is no longer conceivable to foresee a future where democracy only exists at a national level; instead, it will have a European and even global nature [39], due to the way the world is being connected through physical and virtual networks. These networks based on actors, components and strategic relationships, complement, influence and reinforce each other, allowing the educated citizen to be aware of and active in their existence. He or she can decipher the polymorphic nature of the territory as situations that exist and/or are desired $[5,17]$. Education is, therefore, essential for the proper functioning of democracy. Citizens' education level has a great influence on the dynamics of democracy, and the higher it is, the greater is the impact on public participation in policies; this heightens the differences between individuals with varying education levels $[13,40,41]$. Higher educational levels are associated with a better understanding of the main challenges faced in the individual's area, a more critical assessment and awareness of the functioning of political systems and major demonstrations, and a greater accountability in terms of the results of these aspects $[42,43,44,45,46,47]$. Conversely, a lack of sufficient education hinders the dissemination of ideas and information, thus reducing the quality of public participation. However, it is important to ensure that individuals with lower education levels feel confident about participating in public policies, and those with higher education levels must ensure that the information available to their fellow citizens is appropriate, fair and transparent, in addition to ensuring that the discussions taking place within the framework of participation are sufficiently detailed and relevant [48]. This idea is in line with the results obtained from the sample, wherein it was possible to verify that the education level only influences the way in which every citizen accounts for their share of the environmental and spatial planning public policies where they live $(p=0.003)$. In the sample, all citizens with the highest education level $(\mathrm{PhD})$ had participated on a voluntary basis on issues of common goods policies, unlike those with lower education levels $\left(1^{\text {st }}\right.$ cycle $)$, whose participation had only taken place in the format requested, or was not spontaneous at all. The education of individuals should therefore be considered as a factor that empowers them to break from the tradition of passivity [49], and presents itself as an essential tool for the training of citizens; it encourages the emergence and formation of citizenship [40,50,51,52,53]. The need for citizens to be educated and informed of their role and responsibility with regards to participation in society is an idea that has long been championed by several classical authors of political science [54,55,56,57,58,59,60,61]. Of all the socio-economic factors, the education level has the greatest influence on citizens' public participation as it enhances their ability to take ownership of their own desires and interests, and make their voices heard in a logical and organized way $[62,63,64,65,66,67,68]$. The sample presented a high education level, with the integrated master's degree leading the way by being held by $35.8 \%$ of respondents. It would therefore be expected that the sample was very active in environmental and spatial planning public policies; however, this was not the case, since $64.8 \%$ of subjects stated that they "did not participate in public policies". Based on this, the idea emerges that it is not just individuals with higher qualifications that are involved in active citizenship and public participation. This hypothesis is reflected in the results obtained from the sample, wherein individuals with no schooling showed a public participation rate of $42.9 \%$, which is very close to the $44.4 \%$ rate in individuals with the $12^{\text {th }}$ year of schooling, and more than twice that of individuals with an integrated master's degree, which was 20\%. According to Appelstrand [69], Mwenda [67] and Siala [40], individuals' education level does not affect their public participation, but the way in which it is performed. This is in line with the results of the study, wherein we observed that the subjects' education level did not influence their participation in political decisions $(\mathrm{p}=0.960)$. For the question asking at what stage citizens should get involved in the process of public policies, the majority of respondents $(82.4 \%)$ chose the answer "from the beginning of the process". This notion cuts across the sample and was independent of the individuals' education level, since there were no statistically significant differences between subjects with different levels of education $(\mathrm{p}=0.299)$. This tells us that people with lower educational levels also assert their rights in the democratic system, translating into a public participation that can be evaluated as effective [70]. In this sense, the idea that such citizens are less able to complete or take on participatory tasks is wrong. In addition, this would limit the ability of all citizens to participate in 
decision-making, forcing them to accept orders issued by the government, and at all stages of the process, undermining the development regarding the management of common interests and assets $[71,72,73]$. Nowadays participation is an essential element of our democratic societies. Though a wide range of types of participation exist, the deliberative democracy calls for an active participation ensuring that citizen's involvement and intervention go beyond just exercising the voting right. The idea is to have people debating ideas and collaborating towards more representative and fair decisions. It is therefore, deliberative participation that has most likely positive democratic effects. For this to happen, education assumes a central key role, since it is closely related to democracy, public participation, citizenship and sustainable development. It is also seen as a need for the adequate functioning of democratic systems, and therefore as a way to better choices.

\section{Conclusions}

Based on the results obtained from the study, we can conclude that education level influences citizen participation only in terms of how they perceive and carry out their involvement in public policies; but does not affect the fact that they are more or less participatory, since education is not limited to the knowledge acquired in school through the different levels or degrees, but goes far beyond the school walls [50,74]. As Brandão [75] said, "to know, to do, to be and to live every day, mix life with education".

\section{ACKNOWLEDGEMENTS}

The author thank to Anjos of Assis Veterinary Medicine Centre (CMVAA), Barreiro - Portugal, for funding support.

\section{REFERENCES}

[1] Avelar L.(2004).Participação Política. In: AVELAR, Lúcia; CINTRA, Antônio Octávio (Orgs.). Sistema político brasileiro: uma introdução. São Paulo: Unesp

[2] Steffek J, Nanz P.(2008). Emergent patterns of civil society participation in global and European governance. Eds: Palgrave Macmillan

[3] Sánchez-Parga J.(2005).Del conflicto social al ciclo político de la protesta. In: Ecuador Debate, 64, Quito-Ecuador, Abril. Disponível em:http://www.dlh.lahora.com.ec/paginas/debate.

[4] Duarte D.(1996). Procedimentalização, Participação e Fundamentação. Para uma Concretização do Princípio da Imparcialidade Administrativa como Parâmetro Decisório.Edições Almedina, ISBN: 9789724009643

[5] Carreira V.(2009). Urbanismo e Síndrome Depressivo. Tese de mestrado em Ordenamento do Território, apresentada à Faculdade de Ciências e Tecnologia da Universidade Nova de Lisboa para obtenção do título em Mestre de Ciência em Ordenamento do Território, Caparica, Portugal

[6] Carreira V, Machado JR, Vasconcelos L.(2016). Legal citizen knowledge and public participation on environmental and spatial planning policies: Case study in Portugal. International Journal of Humanities and Social Science Research, 2 (7):22-33

[7] Ferreira, J.R.;Marafon, G.J. \& Silva, A.C.P (2013). Governança, Governo e Ordenamento do Território em Contextos Metropolitanos Metropolização do Espaço: Gestão Territorial e relações Urbano-Rurais, Editora Consequência, Rio de Janeiro,:255-281.

[8] Lukensmeyer CJ.(2009). The Next Challenge for Citizen Engagement: Institutionalisation in OECD Focus on Citizens: Public Engagement for Better Policy and Services. Paris: OECD.

[9] Oliveira MA, Carvalho AV, Bartolo L.(2004).Public Discussion of Oporto's Municipal Master Plan: An e-Democracy Service Supported by a GIS, EGOV04, Zaragoza, Spain

[10] Correia JC.(2004).Comunicação e Cidadania: Os Média e a Fragmentação do Espaço Público nas Sociedades Pluralistas. Lisboa. Livro Horizonte

[11] Ferrão J.(2014).O Ordenamento do Território como Política Pública. $2^{\mathrm{a}}$ ed, Fundação Calouste Gulbenkian, Lisboa.

[12] Cohen J, Fung A.(2004).Radical Democracy. Swiss Journal of Political Science,London, 10 (4):23-34.

[13] Pinsky J.(2003).Introdução. In: PINSKY, J.; PINSKY, C. B. (Orgs.). História da cidadania. São Paulo: Contexto:9-13. 
[14] Fung A.(2007).Minipublics: Deliberative Designs and their consequences. In S. W. Rosenberg, Deliberation, Participation and Democracy: Can the people govern? Nova Iorque: Palgrave Macmillan.

[15] Burnett G, Jaeger PT, Thompson KM.(2008)Normative behavior and information: The social aspects of information access. Library \& Information Science Research 30, pp. 56-66

[16] Albareda L, et al. (2008). The Changing Role of Governments in Corporate Social Responsibility: Drivers and Responses, Business Ethics: A European Review, 17(4):347- 363

[17] Cowen DD, Smith N.(2009). After Geopolitics? From the Geopolitical Social to Geoeconomics. Antipode, 41,(1):22-48. DOI: 10.1111/j.1467-8330.2008.00654.x

[18] Cogan C, Sharpe G.(1986). Planning Analysis: The Theory of Citizen Involvement, Available on http://pages.uoregon.edu/rgp/PPPM 613/class10theory.htm

[19] Cury CRJ.(2002).Direito à educação: direito à igualdade, direito à diferença. Cadernos de Pesquisa,116:245-262.Acedidoem:http://www.scielo.br/scielo.php

[20] Gomes C.(2008). O universo do homem social e o lugar da realidade objetiva: um diálogo entre pierre teilhard de chardin e milton santos. Revista bibliográfica de geografía y ciencias sociales, Vol. XIII, nº 772, Universidad de Barcelona , Espanha, ISSN: 1138-9796.

[21] Xavier J, Gouveia LB.(2004).O Relacionamento com o Cidadão. A importância do Território. Conferência Ibero-Americana WWW/Internet, 7 - 8 Outubro, Madrid, Espanha

[22] Tarapanoff K.(2006).Inteligência, informação e conhecimento em corporações /, organizadora. Instituto Brasileiro de Informação em Ciência e Tecnologia - IBICT e Organização das Nações Unidas para a Educação, a Ciência e a Cultura - UNESCO, Brasília

[23] Neto G, Borges R.(2011). Minimalismo schumpeteriano, teoria econômica da democracia e escolha racional. Revista de Sociologia e Política, 19(38):27-42.

[24] Cash D, Clark W, Alcock F, Dickson N, Eckley N, Guston D, Jager J, Mitchell R.(2003). Knowledge systems for sustainable development, PNAS, 100 (14):8066-8091

[25] Quivy R, Van Campenhoudt L.(2008).Manual de investigação em ciências sociais, $2^{\mathrm{a}}$ Edição, Gradiva.

[26] Patton MQ.(2008). Utilization-focused evaluation,in Utilization-focused evaluation, 4th edition. Thousand Oaks, CA: Sage Publications, Inc

[27] Lessard-Hébert M, Goyette G, Boutin G.(2012).Investigação Qualitativa - Fundamentos e Práticas, Instituto Piaget, Epistemologia e Sociedade, $5^{\text {a }}$ edição

[28] Rowe G, Horlick-Jones T, Walls J, Poortinga W, Pidgeon NF.(2008). Analysis of a Normative Framework for Evaluating Public Engagement Exercises: Reliability, Validity and Limitations. Public Understanding of Science, 17(4), 419-441. DOI: 10.1177/0963662506075351

[29] Deshaies B.(1992). Metodologia da investigação em ciências humanas; Lisboa: Instituto Piaget

[30] Johnson RA,Wichern DW.(1992).Applied multivariate statistical analysis. Pearson, Prentice Hall, $6^{\text {th }}$ edition, Upper Saddle River, New Jersey.

[31] Dean AG, Arner TG, Sangam S, Sunki GG, Friedman R, Lantinga M, et al. (2000). Epi Info. Version 3.3. A database and statistics program for public health professionals for use on Windows 95, 98, NT, and 2000 computers. Atlanta, GA: Centers for Disease Control and Prevention.

[32] Massons DJ.(1999). Métodos estadísticos en ciencias de la Salud. Barcelona, Universitat Autònoma de Barcelona

[33] Neto PL.(2002). Estatística. Editora Edgard blücher,2a ed., São Paulo, Brazil

[34] Muñoz T, Garcia.(2003).El Cuestionario como instrumento de investigación / Evaluacion:http://personal.telefonica.terra.es/web/medellinbadajoz/sociologia/El_Cuestionario.p df

[35] Rojas RAO.(2001).El Cuestionario:http://www.nodo50.org/sindpitagoras/Likert.htm

[36] Amaro A, Póvoa A, Macedo L.(2005). A arte de fazer questionários. Metodologias de Investigação em Educação. Faculdade de Ciências, Universidade do Porto

[37] INE.(2012).Censos 2011 Resultados Definitivos - Portugal. Instituto Nacional de Estatística, I.P., Lisboa 
Citizens' Education Level and Public Participation in Environmental and Spatial Planning Public Policies: Case Study in Lisbon and Surrounds Counties

[38] PORTADA.(2015). Base de dados de Portugal Contemporâneo. Fundação Francsico Manuel dos Santos. Acedido em: http://www.pordata.pt/Portugal

[39] Alegre M.(2006).Cidadania e formas de participação cívica. Clube dos Pensadores: http://www.manuelalegre.com/302000/1/000274,000001/index.htm

[40] Siala EO.(2015).Factors Influencing Public Participation In Budget Formulation. The Case Of Nairobi County. Tese de Doutoramento apresentada à United States International University,

[41] Lee J.(2008).Essays on the Determinants and Effects of Public Education Expenditure in Developing Countries. ProQuest

[42] Craveiro MT.(1996). Estudos de Impacte ambiental. Uma contribuição sociológica - A emergência do público nas audiências. LNEC, Lisboa, Portugal

[43] Gil H, Martins S.(1996). Cinco anos de AIA em Portugal. O processo da consulta pública.Ipamb, Portugal

[44] Freire P.(1999). Educação e mudança. São Paulo, Editora:Paz e Terra, Brasil

[45] Lima LC.(2000).A democratização das organizações educativas e a participação como ingerência: contribuições de Paulo Freire. Separata da revista FORUM, 31: 81-94

[46] Martins-Júnior JP, Humberto D.(2004).O Índice de Participação e a importância da educação. Opin. Publica, 10(2)

[47] Sarmento MJ.(2011).Atos de Pesquisa em Educação - PPGE/ME FURB. ISSN.18090354,6(3):581- 602

[48] Moisés JA, Carneiro GP.(2008).Democracia, desconfiança política e insatisfação com o regime: o caso do Brasil.Opinião Pública,14(1):1-42.

[49] Marcondes D.(1997).Iniciação à história da filosofia: dos pré-socráticos a Wittgenstein. 4. ed. Rio de Janeiro: Jorge Zahar Ed.:298

[50] Bobbio N.(1987).O Futuro da Democracia: Uma Defesa das Regras do Jogo. Rio de Janeiro: Paz e Terra: 1986.

[51] Madec A, Murard N.(1998).Numa. Cidadania e Políticas Sociais. Lisboa: Instituto Piaget.

[52] Barata-Moura J.(2003).A Cidadania como Cultivo. In: Philosophica, 22:83-98

[53] Águila R.(2010).La Participación Politica como generadora de educación cívica y gobernabilidad. In: Revista Iberoamericana de Educación, 12.

[54] Kweit MG, Kweit RW.(1981).Implementing Citizen Participation In A Bureaucratic Society: A Contingency Approach 31.Stuart Langton, What is Citizen Participation?,in Citizen Participation In America, 13, 13.

[55] Morais D.(1998). Palavras parabolicas: o mercado editorial na era da mundialização. Editora: Letra livre

[56] Weffort FC.(1998).Os clássicos da política- Maquiavel, Hobbes, Locke, Montesquieu, Rousseau, "O Federalista". Ática , Brasil, 1998, Vol. 1, ISBN: 9788508035427

[57] Spyke NP.(1999).Public Participation in Environmental Decision making at the New Millennium: Structuring New Spheres of Public Influence, 26 B.C. Envtl. Aff. L. Rev. 263

[58] Moisés JA.(2008). Cultura politica, Instituições e Democracia. RBCS,23(66):11-43

[59] Moisés JA.(1995).Os Brasileiros e a Democracia bases sócio-políticas da legitimidade democrática. São Paulo: Ática, Brasil

[60] Libâneo JC.(2002).Adeus professor, adeus professora: novas exigências educacionais e profissão docente. 6 ed. São Paulo: Cortez,Brasil.

[61] Sipioni ME, Silva MZ.(2013).Reflexões e interpretações sobre a participação e a representação em conselhos gestores de políticas públicas. Revista de Sociologia e Política, 21(46):147158.Acedido em:www.scielo.br/scielo.php?script=sci_arttext\&pid

[62] Inglehart R.(2002).Cultura e democracia. IN: Harrison L. \& Huntington, S.(orgs). A cultura importa. Rio de Janeiro, Record.

[63] Milligan K, Moretti E, Oreopoulos.(2004). Does Education Improve Citizenship? Evidence from de United States and United Kingdom. Journal of Public Economics 88: 1667-95 
[64] Dee TS.(2004). Are There Civic Return to Education? Journal of Public Economics, :1697-1720

[65] Gomes W.(2005).Internet e Participação Política em Sociedades Democráticas. In: Revista Famecos, Porto Alegre, 1(17)

[66] Mboga H.(2009).Understanding the Local Government System in Kenya: A Citizens Handbook. Nairobi: IEA-Kenya.

[67] Mwenda A.(2010).Devolution in Kenya: Prospects, Challenges and Future. Nairobi: Institute of Economic Affairs. IEA Research Paper Series, 24:8-13.

[68] Amorim MSS.(2007).Cidadania e Participação Democrática. Anais do II Seminário Nacional de Movimentos Sociais, Participação e Democracia; 5-27 de Abril,UFSC, Florianópolis, Brasil

[69] Appelstrand M.(2002).Participation and societal values: the challenge for lawmakers and policy practitioners. Forest Policy and Economics. 4:281-290

[70] Whitaker F, et al.(1989).Cidadão Constituinte. São Paulo: Paz e Terra, Brasil

[71] Racelis M.(1997). Movilizando la población para el desarrollo social.: enfoques y técnicas para la participación popular. In: KLIKSBERG, Bernardo (comp.) Pobreza: un tema impostergable: nuevas respuestas a nivel mundial. 4. ed. [S.1.]: Fondo de Cultura Económica

[72] Iglesias EV.(1998).Palabras de cierre. In: Seminario Programas Sociales, Pobreza Y Participación Ciudadana. Anais. [S.1.]: BID

[73] Navarro Z.(1998).La democracia afirmativa y el desarrollo redistributivo: el caso del presupuesto participativ o en Porto Alegre, Brasil (1989-98). In: Seminario Programas Sociales, Pobreza Y Participación Ciudadana. Anais.[S.1.]: BID, 1998.

[74] Dahl RA.(2001).Sobre a democracia. Fundacao Universidade De Brasília, Editora UNB

[75] Brandão CR. (1985).O que é educação. 16 Edição. São Paulo: Brasiliense, Brazil 